\title{
Meningites virais
}

\section{Viral meningitis}

Correspondência | Correspondence: Secretaria de Estado da Saúde de São Paulo Av. Dr. Arnaldo, $3511^{\circ}$ andar sala 135 01246-901 São Paulo, SP, Brasil

E-mail: agencia@saude.sp.gov.br

Texto de difusão técnico-científica da Secretaria de Estado da Saúde de São Paulo.

\author{
Divisão de Doenças de Transmissão Respiratória, do Centro de \\ Vigilância Epidemiológica "Prof. Alexandre Vranjac", Coordenado- \\ ria de Controle de Doenças, da Secretaria de Estado da Saúde de \\ São Paulo e Instituto Adolfo Lutz (Laboratório de Vírus Entéricos)
}

A meningite viral caracteriza-se por um quadro clínico de alteração neurológica, que, em geral, evolui de forma benigna. Os casos podem ocorrer isoladamente, embora o aglomerado de casos (surtos) seja comum. Indivíduos de todas as idades são suscetíveis, porém a faixa etária de maior risco é a de menores de cinco anos. Aproximadamente $85 \%$ dos casos são devido ao grupo dos Enterovírus, dentre os quais se destacam os Poliovírus, os Echovírus e os Coxsackievírus dos grupos A e B 1,2. O manejo deve ser adequado para cada etiologia. Apresentam-se a seguir as principais etiologias, manejo, possibilidade diagnóstica e tratamento desta entidade nosológica.

A meningite viral é geralmente benigna, na maioria dos casos com líquor de celularidade de 50 a 500 células/mm, com predomínio de linfomononuclear. Caracteriza-se por um quadro clínico de alteração neurológica que, em geral, evolui de forma benigna. Os casos podem ocorrer isoladamente, embora o aglomerado de casos (surtos) seja comum. Indivíduos de todas as idades são suscetíveis, mas a faixa etária de maior risco é a de menores de cinco anos (Tabela).

\section{Agentes etiológicos mais freqüentes}

No grupo dos Enterovírus, destacam-se os da família Picornaviridae: Echovirus (3, 4e, 6, 9, 11, 75, 21 e 30) os Poliovírus e os Coxsackievírus dos grupos A e B 1,2.

Tabela - dar um titulo para ela, nao tem nome a tabela, dar um titulo pra ela.

\begin{tabular}{ll}
\hline Vírus RNA & Vírus DNA \\
\hline Enterovírus & Adenovírus \\
Arbovírus & Herpes simples tipo 1 e 2 \\
Vírus do sarampo & Varicela zoster \\
Vírus da caxumba & Epstein Barr \\
Vírus da Coriomeningite & \\
linfocitária (arenavírus) & Citomegalovírus \\
HIV 1 & - \\
\hline
\end{tabular}

Trabalho realizado em quatro Estados brasileiros isolou em amostras de líquor cefalorraquidiano (LCR) os Enterovírus em 162 (15,8\%) em 1.022 analisados. A transmissão é de pessoa a pessoa, e varia de acordo com o agente etiológico, sendo fecal-oral, no caso dos enterovírus.

Os Enterovírus têm comportamento sazonal, predominando na primavera e verão, podendo ocorrer em número menor nas outras estações do ano. A duração da doença geralmente é menor que uma semana. Os lactentes são os mais suscetíveis e a reinfecção pode ocorrer por sorotipos diferentes.

Outros grupos menos freqüentes são: os arbovírus, o herpes simples vírus e os vírus da varicela, da caxumba e do sarampo. $\mathrm{O}$ vírus da caxumba é um agente comum em população não imunizada, predominando entre préescolares, escolares e estendendo-se a adolescentes e adultos jovens. $\mathrm{O}$ vírus da coriomeningite linfocitária é de ocorrência rara, sendo transmitida por contato direto ou indireto com as excretas de roedores. A via de transmissão é a digestiva, pela contaminação de alimentos com a urina do roedor ou exposição de feridas; não há transmissão interhumana nesta etiologia.

Os herpes vírus (HSV-1 e HSV-2) são responsáveis por $0,5 \%$ a $3 \%$ dos casos de meningite viral aguda. São quadros autolimitados, todavia, quando cursam com encefalite, são potencialmente fatais e estão associados ao HSV-2.

No grupo dos arbovírus merece destaque o vírus do Nilo Ocidental, que nos últimos anos tem sido responsável por vários casos de encefalite e meningite em indivíduos acima de 50 anos, principalmente na América do Norte. O Citomegalovírus, o vírus Epstein Barr (EB) e os arbovírus são responsáveis por 5\% a $10 \%$ dos casos, nas infecções primárias. A meningite 


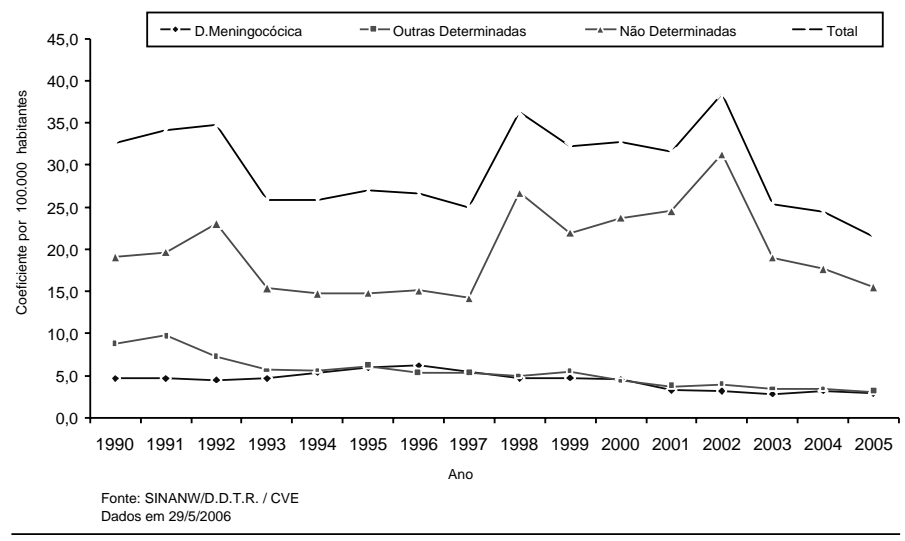

Figura 1 - Incidência de meningites, segundo etiologia. Estado de São Paulo, 1990 a 2005

recorrente de Mollaret está associada ao HSV-1, HSV2, EB vírus e o herpes vírus tipo 6. A transmissão é de pessoa a pessoa, e varia de acordo com o agente etiológico, sendo fecal-oral, no caso dos enterovírus.

\section{Características clínicas e laboratoriais}

A meningite é mais freqüente nos meses quentes e caracteriza-se por quatro síndromes, podendo cursar com as seguintes características:

- síndrome infecciosa: febre ou hipotermia, anorexia, apatia e sintomas gerais de um processo infeccioso;

- síndrome de irritação radicular com sinais meníngeos característicos: rigidez de nuca, sinais de Köernig, Brudzinski e Lasègue;

- síndrome de hipertensão intracraniana: cefaléia, vômitos sem relação com a alimentação, fundo de olho com edema de papila e,

- síndrome encefalítica: caracterizada por sonolência ou agitação, torpor, delírio e coma.

A gravidade dependerá do agente etiológico, habilidade da equipe de saúde, diagnóstico precoce, faixa etária e estado imune do paciente. Apesar de a maioria dos casos evoluir de forma autolimitada e benigna, pode haver seqüelas como retardo mental, surdez,

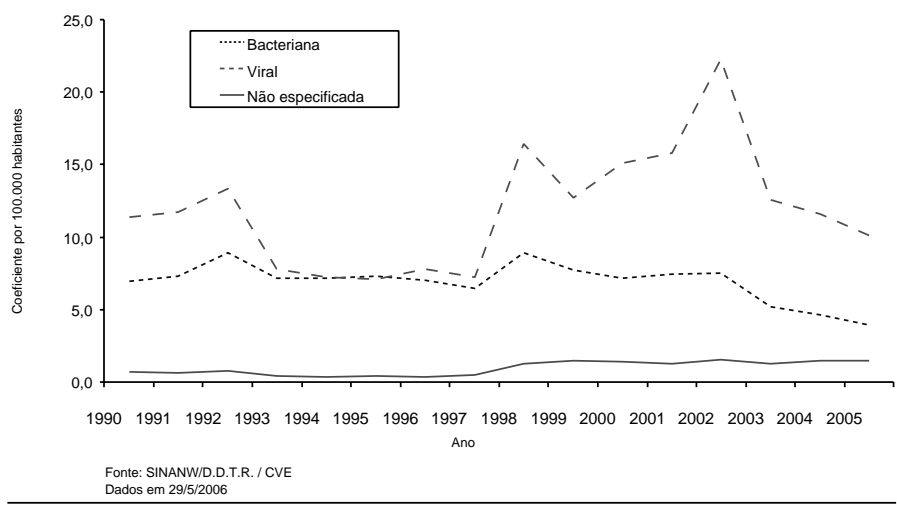

Figura 2 - Incidência de meningites não determinadas segundo provável etiologia. Estado de São Paulo, 1990 a 2005. convulsões e perdas motoras ou sensoriais. O diagnóstico deve ser precoce e na suspeita deve-se realizar punção liquórica, de preferência lombar, entre L3 e S1. Para a punção ser realizada de forma segura, é importante realizar-se exame de fundo de olho nos adultos e em crianças com fontanela fechada.

$\mathrm{O}$ aspecto do líquor é geralmente claro nas meningites virais, com menos de 500 células, mas na caxumba, pode haver turbidez devido à quantidade de células, de 300 a 3.000; o predomínio inicial é de neutrófilos, podendo alterar para linfomonocitário em seis a 48 horas. Deve-se tomar cuidado para não confundir com as meningites bacterianas parcialmente tratadas pelo uso de antibióticos prévios.

Na bioquímica do líquor costumeiramente há proteína, cloreto e glicose normais ou com discreta alteração. O nível normal de glicose do líquor corresponde a dois terços da glicemia normal, a proteína pode variar de 15 a $45 \mathrm{mg} / \mathrm{dl}$ e o cloreto, de 680 a $750 \mathrm{mg} / \mathrm{dl}$.

Para a tentativa de isolamento dos Enterovírus deverão ser testadas amostras de líquor e fezes, além da pesquisa de anticorpos em amostras pareadas de soro.

No caso dos herpes vírus e citomegalovírus, pode ser realizada a reação em cadeia de polimerase (PCR), no LCR.

\section{Epidemiologia, vigilância e controle}

No Brasil, em média, são notificados 11.500 casos/ ano de meningite de provável etiologia viral. Entretanto, para a maioria dos casos não há identificação do agente etiológico.

A Figura 1 apresenta os coeficientes das meningites por etiologia, nos últimos 15 anos, no Estado de São Paulo, com destaque para as meningites não determinadas, na qual estão inseridas as meningites de provável etiologia viral. Observa-se na Figura 2 o comportamento das meningites não determinadas, de 1990 a 2005, em território paulista, onde se evidencia a meningite de provável etiologia viral com incidência média de 11,74/100.000 habitantes e tendência a declínio a partir do ano de 2002.

A identificação de agentes virais causadores de meningite no Brasil só tem sido possível em algumas situações, como surtos, nas quais existe um esforço conjunto para $\mathrm{o}$ esclarecimento etiológico. Sendo assim, o sistema de vigilância epidemiológica de 
meningites dispõe de poucos dados sobre os principais agentes.

A Divisão de Doenças de Transmissão Respiratória, do Centro de Vigilância "Prof. Alexandre Vranjac" (DDTR/CVE) - órgãos da Coordenadoria de Controle de Doenças, da Secretaria de Estado da Saúde de São Paulo (CCD/SES-SP) -, em parceria com o Ministério da Saúde, Instituto de Infectologia Emílio Ribas (IIER) e Casa de Saúde Santa Marcelina, iniciou um Protocolo de Implementação de Vigilância de Meningites Virais no Estado, desde outubro de 2005. Essa ação tem por objetivos:

- aumentar a especificidade do sistema e conhecer os principais Enterovírus causadores de meningite;

- verificar o comportamento epidemiológico em relação às meningites virais; aprimorar a detecção e o esclarecimento diagnóstico em situações de surto; melhorar a qualidade dos dados do sistema de informação. A abordagem de rotina para a vigilância de meningite viral compreende a estrutura e a metodologia já existentes para a vigilância de meningite.

\section{Definição de caso}

Considera-se caso suspeito de meningite o indivíduo que apresentar três ou mais dos seguintes sinais e sintomas: cefaléia, vômito, rigidez de nuca, sinais de irritação meníngea (Kernig e Brudzinsky) ou abaulamento de fontanela (em menores de um ano), sonolência e convulsão. Outros sinais e sintomas que podem estar presentes são: fotofobia, exantema, diarréia e mialgia.

Considera-se como meningite de provável etiologia viral: caso suspeito com líquor de aspecto límpido e celularidade apresentando pleocitose, com predomínio de mononucleares. Para se considerar caso confirmado: caso provável de meningite viral com confirmação laboratorial ou história de vínculo epidemiológico com caso confirmado laboratorialmente por isolamento e identificação.

\section{Definição de surto}

Surto ou epidemia pode ser definido como ocorrência de uma doença em uma freqüência inesperada. Para fins de vigilância, utiliza-se a seguinte classificação de surto:

- Comunidade institucional (escola, creche, acampamento e alojamento): ocorrência de dois ou mais casos suspeitos de meningite num intervalo de até três semanas.

- Comunidade aberta (bairro, município e outros): ocorrência do dobro do número de casos espera- dos de meningite de provável etiologia viral por três semanas sucessivas.

Devem ser selecionados pacientes que se enquadrem na definição de caso de meningite de provável etiologia viral. No contexto de surto, não serão analisadas amostras de todos os casos; por isso, a pesquisa viral será limitada a no máximo 20 amostras biológicas, conforme sugestão do laboratório de referência no Estado de São Paulo, o Instituto Adolfo Lutz (IAL).

Além do líquor, deverão ser coletadas amostras de fezes e soro pareado dos casos:

- líquor: $2 \mathrm{ml}$ a $5 \mathrm{ml}$;

- fezes: 4 a 8 gramas (1/3 do coletor universal);

- soro: $5 \mathrm{ml}$ de sangue sem anticoagulante.

As amostras de soro pareadas deverão ser coletadas: uma amostra em fase aguda e outra em fase convalescente (após 15 dias da data do início dos sintomas). São processadas somente as amostras pareadas.

Na ocorrência de surto deverão ser selecionados, preferencialmente, pacientes que apresentem quadro clínico mais sugestivo, encontrem-se em fase aguda da doença e que seja possível o encaminhamento de todas as amostras (líquor, fezes e soro pareado). Nesse caso, usar o instrumento de notificação, ou seja, o Boletim de Notificação de Surtos do Sistema Nacional de Agravos de Notificação (Sinan). O Protocolo de Coleta para o Diagnóstico Laboratorial dos Enterovírus encontra-se disponível no site* do Centro de Vigilância Epidemiológica.

\section{Tratamento}

O tratamento das meningites virais é de suporte: antitérmicos como dipirona, antieméticos (metoclopramida), cabeceira elevada a $30^{\circ}$. Se o paciente estiver sonolento ou confuso ou com dificuldade de deglutição, deverá ser mantida sonda nasogástrica para hidratação adequada e evitar broncoaspiração. Nos casos de herpes vírus pode ser utilizado o aciclovir com a seguinte posologia: $10 \mathrm{mg} / \mathrm{kg} / \mathrm{dose}$ a cada oito horas, por 14 a 21 dias. A punção liquórica alivia a cefaléia por diminuir a pressão intracraniana. Os casos de internação são excepcionais, apenas para evitar a desidratação provocada pelos vômitos, diminuir a cefaléia e melhorar as condições gerais. $\mathrm{O}$ uso de corticosteróides é discutível, assim como a gamaglobulina.

Em surtos do tipo caxumba, faz-se busca ativa dos casos e o bloqueio da transmissão por meio da imunização. 